\title{
Correction to: The peptide transporter 1a of the zebrafish Danio rerio, an emerging model in nutrigenomics and nutrition research: molecular characterization, functional properties, and expression analysis
}

Francesca Vacca ${ }^{1 \dagger}$, Amilcare Barca ${ }^{2 \dagger}$, Ana S. Gomes ${ }^{3}$, Aurora Mazzei $^{2}$, Barbara Piccinni ${ }^{2,4}$, Raffaella Cinquetti ${ }^{1}$, Gianmarco Del Vecchio ${ }^{2}$, Alessandro Romano ${ }^{5}$, Ivar Rønnestad ${ }^{3 *}$, Elena Bossi ${ }^{{ }^{*}}$ and Tiziano Verri ${ }^{{ }^{*}}$

Correction to: Genes Nutr (2019) 14:33

https://doi.org/10.1186/s12263-019-0657-3

Following publication of the original article [1], the authors flagged that the 'Availability of data and materials' declaration is incomplete.

Namely, it does not report the official accession number for the zebrafish PepT1a nucleotide sequence.

With concern to this, please see the (correct) 'Availability of data and materials' declaration here:

"Zebrafish pept1a (slc15a1a) nucleotide sequence has been submitted to GenBank (https://www.ncbi.nlm. nih.gov/nuccore/) and is available with the following accession number: GenBank Acc. No. MN723161"

The authors apologize for any inconvenience caused.

\section{Author details}

'Department of Biotechnology and Life Sciences, University of Insubria, via

J.H. Dunant 3, 21100 Varese, Italy. ${ }^{2}$ Department of Biological and Environmental Sciences and Technologies, University of Salento, via Provinciale Lecce-Monteroni, I-73100 Lecce, Italy. ${ }^{3}$ Department of Biological Sciences, University of Bergen, P.O. Box 7803, NO-5020 Bergen, Norway.

${ }^{4}$ Present address: Physiopathology of Reproduction and IVF Unit, Nardò Hospital, Nardò Health and Social Care District, Lecce Local Health Agency, I-73048 Nardò, Lecce, Italy. ${ }^{5}$ Division of Neuroscience, Institute of

Experimental Neurology, IRCCS San Raffaele Scientific Institute, I-20132 Milan, Italy.

Published online: 07 February 2020

\section{Reference}

1. Vacca F, et al. The peptide transporter 1a of the zebrafish Danio rerio, an emerging model in nutrigenomics and nutrition research: molecular characterization, functional properties, and expression analysis. Genes Nutr. 2019;14:33. https://doi.org/10.1186/s12263-019-0657-3.

*Correspondence: Ivar.Ronnestad@uib.no; Elena.Bossi@uninsubria.it; tiziano.verri@unisalento.it

${ }^{\dagger}$ Francesca Vacca and Amilcare Barca contributed equally to this work. ${ }^{3}$ Department of Biological Sciences, University of Bergen, P.O. Box 7803 NO-5020 Bergen, Norway

'Department of Biotechnology and Life Sciences, University of Insubria, via J.H. Dunant 3, 21100 Varese, Italy

${ }^{2}$ Department of Biological and Environmental Sciences and Technologies, University of Salento, via Provinciale Lecce-Monteroni, I-73100 Lecce, Italy Full list of author information is available at the end of the article

(c) The Author(s). 2020 Open Access This article is distributed under the terms of the Creative Commons Attribution 4.0 International License (http://creativecommons.org/licenses/by/4.0/), which permits unrestricted use, distribution, and reproduction in any medium, provided you give appropriate credit to the original author(s) and the source, provide a link to the Creative Commons license, and indicate if changes were made. The Creative Commons Public Domain Dedication waiver (http://creativecommons.org/publicdomain/zero/1.0/) applies to the data made available in this article, unless otherwise stated. 